\title{
Efficacy of Bio-Intensive integrated pest management against brinjal shoot and fruit borer Leucinides orbonalis (Lepidoptera: Crambidae)
}

\author{
Niranjana, R F1\&2, Devi, $\mathbf{M}^{2}$ and Sridhar, $R \mathbf{P}^{2}$ \\ ${ }^{1}$ Department of Agricultural Biology, Faculty of Agriculture, Eastern University, Sri Lanka, \\ ${ }^{2}$ Department of Agricultural Entomology, Tamil Nadu Agricultural University, Coimbatore 641003, \\ Tamil Nadu, India
}

\begin{abstract}
Brinjal (Solanum melongena) plays a vital role in the food of South-Asian people, thus the production of brinjal in these countries is quite high. However the production of brinjal does not satisfy the whole demand of people owing to the severe infestation by L. orbonalis. In order to get maximum yield from the cultivation farmers rely on over and indiscriminate use of chemical insecticides. Due to the side effects of over and indiscriminate use of toxic insecticides, now the trend moves towards Bio-intensive Integrated Pest Management (BIPM). The present study conducted to find the efficacy of BIPM over farmer's practices and untreated control in controlling the L. orbonalis. The study evidenced the superiority of BIPM in all aspects viz., lesser shoot infestation (15.82 percent), greatest yield $(17,170.22 \mathrm{~kg} / \mathrm{ha})$ and higher natural enemies activities (5.25 no./10plants), which was equivalent to untreated control. Besides the treatment BIPM proved its efficacy over farmer's practice and untreated control especially with high percent increase of yield $(63.90 \%)$, percent reduction of shoot $(64.01 \%)$ and fruit infestation $(80.58 \%)$, and less percent reduction of natural enemies' population $(8.70 \%)$. Apart from this the benefit cost ratio (BCR) ranked in the order of superiority as BIPM module (1:5.75), which was greater than the farmer practice (1:4.96) on brinjal.
\end{abstract}

Keyword: Brinjal; Bio-intensive; Integrated Pest Management; Leucinodes orbonalis

\section{Introduction}

The brinjal (Solanum melongena) is the native to Indian Subcontinent (Tsao and Lo 2006; Doijode 2001) and belongs to the family Solanaceae (Nightshade). It contributes $9 \%$ of the total vegetable production of India (Sidhu and Dhatt, 2007). Although brinjal plays a major role in the food of South-Asian people the production is relatively low due to the infestation of shoot and fruit borer, Leucinode sorbonalis Guenée (Crambidae: Lepidoptera). As the inhabiting nature of this pest protects it from the control practices, the farmers rely on the overuse of chemical insecticide. Rather than giving the satisfactory control of L. orbonalis, the indiscriminate use of toxic, broadspectrum pesticides kill the natural enemies of L. orbonalis, which were giving satisfactory control of the pest before the use of insecticides became widespread (Talekar 2002). It was noted from the study that the agreeable level of control was achieved by the parasitoid Trathala flavoorbitalis (Talekar 2002) in the brinjal fields of South and Southeast Asian countries prior to the extensive use of insecticides. Besides, indiscriminate use of pesticides in brinjal resulted in development of resurgence of secondary pests such as whitefly, mites and thrips (Krishnakumar and Krishnamoorthy, 2001). By considering these drawbacks in brinjal cultivation, the present study was carried out to assess the efficacy of Biointensive Integrated Pest Management against L. orbonalis. https:/ / orcid.org/0000-0002-4272-4870

Accepted: 07.11.2018 


\section{Materials and Methods}

\subsection{Experimental setup}

The field experiments were carried out to evaluate bio-intensive integrated pest management (BIPM) against L. orbonalis on brinjal (var. Pusa Purple Round) at Muddaththuvayal, Semmedu, Coimbatore, India during November 2014 to April 2015. Experiments were conducted in a Randomized Block Design (RBD) with the spacing of $60 \times 60 \mathrm{~cm}$ for brinjal. BIPM module was evaluated in larger plot with an area of 0.5 ha. BIPM module, farmer's practice and untreated control were divided into eight equal segments and considered each one as a replication. To avoid spray contamination $5 \mathrm{~m}$ distance was maintained between treatment plots. All agronomic practices except management practices against $L$. orbonalis were followed regularly.

\subsection{BIPM module}

In BIPM module treated plots (Table 1), the activity of adults L. orbonalis was monitored by the installation of sex pheromone traps. The traps were installed at the plot once after the proper notification of adult moths at the field just after 15 days of transplanting and at the rate of 5 traps/ac. The sex pheromone, Lucin-lure $^{\circledR}$ and Wota-T traps were obtained at Pest Control India (Pvt) Ltd. The pheromone lure was replaced by 21 days interval (Lalitha Kumari and Reddy, 1992; Patil and Mamadapur, 1996; Loganathan et al., 1999) until the end of cropping season. According to the knowledge of adults' activity in brinjal field (Table 2), a combination of management practices was applied properly on time to reduce the infestation of L.orbonalis.

Soon after the notification of adult moths, the egg parasitoids Trichogramma pretiosum (Niranjana et al., 2015) or $T$. embryophagum were released alternately to the field at the rate of 100000 eggs/ac at 10 days interval during late evening. The ovicidal insecticide, Acetamipride $20 \%$ SP was sprayed 5 weeks after the trap installation as higher numbers of adult moths observed in traps.

It was believed that the L.orbonalis was in larval or pupal stages when the least catches were in traps. Thus, entomopathogen, Lecanicillium lecanii was sprayed at $3^{\text {rd }}, 7^{\text {th }}$ and $15^{\text {th }}$ week after trap installation as larvicidal biopestidies. Further NSKE 5\% was sprayed at $4^{\text {th }}, 8^{\text {th }}$, $12^{\text {th }}$ and $16^{\text {th }}$ week after trap installation. Chlorantraniliprole $18.5 \%$ SC was sprayed at $11^{\text {th }}$ week after trap installation as one time spray.

\subsection{Farmer's practice and untreated control modules}

In Farmer's Practice module treated plots, the management practices against L.orbonalis generally adapted by farmers were undertaken and in untreated plots, no treatments were carried out. The treatment details in each module are listed in Table 1.

\subsection{Parameters measured}

The infested shoots of brinjal by $L$. orbonalis, and population of natural enemies except released parasitoids viz., Coccinellids, Chrysopids, Mirids, Oxyopids and Anisopterans were counted from 10 randomly selected plants at weekly interval since 15 days after transplanting whereas infested fruit by $L$. orbonalis were recorded from 60 days after transplanting at each harvesting. The activities of natural enemies were observed carefully at the brinjal field to do visual counts. The per cent shoot and fruit infestation was calculated by counting healthy and infested shoots and fruits at each observation. Economic analysis of BIPM module involving yield and the benefit cost ratio (BCR) were estimated. 


\subsection{Data Analysis}

The per cent shoot and fruit infestation and numbers of natural enemies viz., Coccinellids, Chrysopids, Mirids, Oxyopids and Anisopterans were

Table 1: Details of Bio-intensive IPM subjected to ANOVA once after the arcsine and square root tranformation respectively. All the comparisons were considered significant when $0.05>p<0.01$.

\begin{tabular}{|l|l|}
\hline Module & \multicolumn{1}{|c|}{ Components } \\
\hline Farmer's practice & $\begin{array}{l}\text { Spraying of Thiacloprid 21.7\% SC @ 2.0 g/lit or Chlorantraniliprole 18.5\% } \\
\text { SC @ 4.0 ml/10lit or Flubendiamide 20\% WG @ 7.5 g/10lit at five days } \\
\text { interval on brinjal }\end{array}$ \\
\hline \multirow{3}{*}{ Bio-intensive IPM } & Installation of sex pheromone traps (Lucin-Lure ${ }^{\circledR}$ ) @ 5 per ac for monitoring \\
\cline { 2 - 2 } & $\begin{array}{l}\text { Releasing of Trichogramma pretiosum or T. embryophagum @ 100,000 eggs } \\
/ \text { ac in an alternate manner at 10days interval from 15 days after transplanting }\end{array}$ \\
\cline { 2 - 2 } & Spraying of Acetamipride 20\% SP @ 2 g/101 \\
\cline { 2 - 2 } & Spraying of entomopathogens Lecanicillium lecanii @ 2 x 109 conidia per ml \\
\cline { 2 - 2 } & Spraying of NSKE 5\% \\
\cline { 2 - 2 } & Spraying of Chlorantraniliprole 18.5\% SC @ $4.0 \mathrm{ml} / 10$ lit \\
\hline Untreated Control & No treatments \\
\hline
\end{tabular}

Table 2. Adults of $\boldsymbol{L}$. orbonalis caught in sex pheromone trap

\begin{tabular}{|c|c|c|c|c|c|}
\hline $\begin{array}{c}\text { Time (week } \\
\text { after the trap } \\
\text { installation) }\end{array}$ & $\begin{array}{c}\text { Adults of } \\
\boldsymbol{L} . \\
\text { orbonalis } \\
\text { caught in } \\
\text { trap } \\
\text { (Nos.)* }\end{array}$ & $\begin{array}{c}\text { Time (week } \\
\text { after the trap } \\
\text { installation) }\end{array}$ & $\begin{array}{c}\text { Adults of } \\
\boldsymbol{L} . \\
\text { orbonalis } \\
\text { caught in } \\
\text { trap } \\
\text { (Nos.)* }\end{array}$ & $\begin{array}{c}\text { Time (week } \\
\text { after the trap } \\
\text { installation) }\end{array}$ & $\begin{array}{c}\text { Adults of } \boldsymbol{L} . \\
\text { orbonalis caught } \\
\text { in trap (Nos.)* }\end{array}$ \\
\hline $1^{\text {st }}$ & 27.6 & $7^{\text {th }}$ & 0.7 & $13^{\text {th }}$ & 11.7 \\
\hline $2^{\text {nd }}$ & 28.9 & $8^{\text {th }}$ & 0.0 & $14^{\text {th }}$ & 13.4 \\
\hline $3^{\text {rd }}$ & 1.9 & $9^{\text {th }}$ & 15.3 & $15^{\text {th }}$ & 1.6 \\
\hline $4^{\text {th }}$ & 0.6 & $10^{\text {th }}$ & 12.5 & $16^{\text {th }}$ & 2.1 \\
\hline $5^{\text {th }}$ & 31.8 & $11^{\text {th }}$ & 0.7 & $17^{\text {th }}$ & 12.1 \\
\hline $6^{\text {th }}$ & 25.5 & $12^{\text {th }}$ & 0.8 & $18^{\text {th }}$ & 13.1 \\
\hline
\end{tabular}

*Values are mean of 5 observations

\section{Results and Discussion}

BIPM module evaluated against $L$. orbonalison brinjal recorded a lesser shoot and fruit infestation of L. orbonalis (15.82 per cent) as compared to farmer's practice (17.31 per cent) and untreated control (43.92 per cent) (Table 3) at the end of picking. The management practices against $L$. orbonalisin BIPM were undertaken based on the mean number of adult, L. orbonalis caught in sex pheromone traps. As per the knowledge of trap catches, it can be easy to predict the life stages of L. orbonalis exist in brinjal crops and based on that ovicidal and larvicidal insecticides can be applied on proper time. It can reduce the unnecessary use of insecticides as well as expenses.

Maximum yield was recorded from BIPM module $(17,170.22 \mathrm{~kg} / \mathrm{ha})$ as compared to untreated control $(6,198.63 \mathrm{~kg} / \mathrm{ha})$. The natural enemies viz., Coccinellids, Chrysopids, Mirids, Oxyopids and 
Anisopterans activities in BIPM (5.25 no./10plants) were also high and which was equivalent to the untreated control (Table 3).

Table 3. Evaluation of BIPM module against L. orbonalis on brinjal

\begin{tabular}{|c|c|c|c|c|c|c|c|c|c|}
\hline \multirow[b]{2}{*}{$\begin{array}{c}\text { Treatmen } \\
\text { ts }\end{array}$} & \multicolumn{4}{|c|}{ First Picking* } & \multicolumn{4}{|c|}{ Last Picking* } & \multirow[b]{2}{*}{$\begin{array}{l}\text { Total } \\
\text { Yield } \\
(\mathrm{kg} / \mathrm{ha})\end{array}$} \\
\hline & $\begin{array}{c}\text { Shoot } \\
\text { infestati } \\
\text { on (Per } \\
\text { cent) }\end{array}$ & $\begin{array}{l}\text { Yield } \\
\text { (kg/ac) }\end{array}$ & $\begin{array}{c}\text { Dama } \\
\text { ged } \\
\text { fruit } \\
\text { (Per } \\
\text { cent) }\end{array}$ & $\begin{array}{c}\text { Natura } \\
1 \\
\text { enemi } \\
\text { es } \\
\text { (Nos. / } \\
10 \\
\text { plants) }\end{array}$ & $\begin{array}{c}\text { Shoot } \\
\text { infestati } \\
\text { on (Per } \\
\text { cent) }\end{array}$ & $\begin{array}{l}\text { Yield } \\
\text { (kg/ac) }\end{array}$ & $\begin{array}{c}\text { Dama } \\
\text { ged } \\
\text { fruit } \\
\text { (Per } \\
\text { cent) }\end{array}$ & $\begin{array}{c}\text { Natura } \\
1 \\
\text { enemi } \\
\text { es } \\
\text { (Nos./ } \\
10 \\
\text { plants) }\end{array}$ & \\
\hline BIPM & $\begin{array}{l}11.11^{a} \\
(19.46)\end{array}$ & $\begin{array}{c}221.62^{\mathrm{a}} \\
(14.89)\end{array}$ & $\begin{array}{c}18.71^{\mathrm{a}} \\
(25.62 \\
)^{2}\end{array}$ & $\begin{array}{l}4.75^{b} \\
(2.18)\end{array}$ & $\begin{array}{l}15.82^{a} \\
(23.42)\end{array}$ & $\begin{array}{c}286.11^{a} \\
(16.91)\end{array}$ & $\begin{array}{l}16.22^{a} \\
(23.73)\end{array}$ & $\begin{array}{l}5.25^{\mathrm{a}} \\
(2.29)\end{array}$ & $\begin{array}{c}17,170 . \\
22\end{array}$ \\
\hline $\begin{array}{l}\text { Farmer's } \\
\text { practice }\end{array}$ & $\begin{array}{l}12.81^{b} \\
(20.96)\end{array}$ & $\begin{array}{c}202.33 \text { b } \\
(14.22)\end{array}$ & $\begin{array}{c}20.31^{a} \\
(26.78 \\
)^{a} \\
\end{array}$ & $\begin{array}{l}2.25^{c} \\
(1.50)\end{array}$ & $\begin{array}{l}17.31 \text { a } \\
(24.58)\end{array}$ & $\begin{array}{c}274.81^{b} \\
(16.58)\end{array}$ & $\begin{array}{l}18.13 \text { a } \\
(25.18)\end{array}$ & $\begin{array}{l}1.75^{b} \\
(1.32)\end{array}$ & $\begin{array}{c}16,488 . \\
66\end{array}$ \\
\hline $\begin{array}{l}\text { Untreate } \\
\text { d control }\end{array}$ & $\begin{array}{l}32.74^{c} \\
(34.88)\end{array}$ & $\begin{array}{c}83.23 \text { c } \\
(9.12)\end{array}$ & $\begin{array}{c}31.26^{c} \\
(33.96 \\
\quad) \\
\end{array}$ & $\begin{array}{l}5.25 \mathrm{a} \\
(2.29)\end{array}$ & $\begin{array}{l}43.92 \text { b } \\
(41.50)\end{array}$ & $\begin{array}{c}103.33^{c} \\
(10.16)\end{array}$ & $\begin{array}{l}83.42^{c} \\
(65.96)\end{array}$ & $\begin{array}{l}5.75^{a} \\
(2.40)\end{array}$ & $\begin{array}{c}6,198.6 \\
3\end{array}$ \\
\hline $\begin{array}{c}\text { SEd } \\
\mathrm{CD}(0.05) \\
\mathrm{CD}(0.01)\end{array}$ & $\begin{array}{l}0.51 \\
1.10 \\
1.53\end{array}$ & $\begin{array}{l}0.27 \\
0.58 \\
0.80\end{array}$ & $\begin{array}{l}0.82 \\
1.78 \\
2.46\end{array}$ & $\begin{array}{l}0.05 \\
0.10 \\
0.14\end{array}$ & $\begin{array}{l}0.86 \\
1.84 \\
2.56\end{array}$ & $\begin{array}{l}0.09 \\
0.18 \\
0.26\end{array}$ & $\begin{array}{c}4.54 \\
9.74 \\
13.52\end{array}$ & $\begin{array}{l}0.06 \\
0.12 \\
0.17\end{array}$ & \\
\hline
\end{tabular}

*Values are mean of eight replications

Values in parentheses are arcsine and square root $(\sqrt{x+5})$ transformations.

In each column, means with similar alphabets do not vary significantly at $\mathrm{P}=0.05$ and $\mathrm{P}=0.01$ by DMRT.

The net profit and benefit cost ratio (BCR) were also higher in BIPM module than the farmer's practice. BIPM was found to be superior to farmer's practice in all aspects in the brinjal field experiment. As per the data displayed in Table 4, it was found that the per cent increase of yield (63.90 and 62.41 per cent in BIPM and farmer's practice respectively), and per cent reduction of shoot (64.01 and 60.59 per cent in BIPM and farmer's practice respectively) and fruit infestation (80.58 and 78.30 per cent in BIPM and farmer's practice respectively) over untreated control was high in BIPM than farmer's practice. On the other hand, the percent reduction of natural enemies' population was low in BIPM (8.70 per cent) than farmer's practice (69.57 per cent). Though there was no significant difference between BIPM and un-treated control in the aspect of natural enemies population at the time of $2^{\text {nd }}$ picking, slight reduction (8.7 per cent) was observed due to the application of Acetamipride $20 \%$ SP and Chlorantraniliprole $18.5 \%$ SC at the time of vegetative and early fruiting time of brinjal in BIPM treated plots. Benefit cost ratio (BCR) ranked in the order of superiority as BIPM module (1:5.75), which was greater than the farmer's practice (1:4.96) on brinjal (Table 5). 
Table 4. Effect of BIPM module on shoot and fruit infestation, yield and natural enemies' populations on brinjal

\begin{tabular}{|c|c|c|c|c|}
\hline Treatments & $\begin{array}{c}\text { Per cent } \\
\text { yield } \\
\text { increase } \\
\text { over } \\
\text { untreated } \\
\text { control }\end{array}$ & $\begin{array}{c}\text { Per cent } \\
\text { reduction in } \\
\text { shoot } \\
\text { infestation } \\
\text { over untreated } \\
\text { control }\end{array}$ & $\begin{array}{c}\text { Per cent } \\
\text { reduction in } \\
\text { fruit } \\
\text { infestation } \\
\text { over untreated } \\
\text { control }\end{array}$ & $\begin{array}{c}\text { Per cent } \\
\text { reduction in } \\
\text { natural } \\
\text { enemies' } \\
\text { population over } \\
\text { untreated } \\
\text { control }\end{array}$ \\
\hline BIPM & 63.90 & 64.01 & 80.58 & 8.70 \\
\hline Farmer's practice & 62.41 & 60.59 & 78.30 & 69.57 \\
\hline
\end{tabular}

Table 5. Cost Benefit Ratio

\begin{tabular}{|c|c|c|c|c|c|}
\hline Treatments & $\begin{array}{c}\text { Yield of } \\
\text { healthy } \\
\text { fruits } \\
\text { (kg/ha) }\end{array}$ & $\begin{array}{c}\text { Additional } \\
\text { yield over } \\
\text { control } \\
\mathbf{( k g / h a )}\end{array}$ & $\begin{array}{c}\text { Additional } \\
\text { returns } \\
\text { (Rs.) }\end{array}$ & $\begin{array}{c}\text { Cost of } \\
\text { treatments } \\
\text { (Rs.) }\end{array}$ & $\begin{array}{c}\text { Cost } \\
\text { Benefit }\end{array}$ \\
\hline BIPM & $17,170.22$ & $10,971.60$ & 603438.00 & 105.025 .00 & $1: 5.75$ \\
\hline $\begin{array}{c}\text { Farmer's } \\
\text { practice }\end{array}$ & $16,488.63$ & $10,290.00$ & 565950.00 & $114,200.00$ & $1: 4.96$ \\
\hline Control & $6,198.61$ & - & - & - & - \\
\hline
\end{tabular}

Mandal et al. (2008a) found that the internal rate of return as well as benefitcost ratio was very high in IPM adopted brinjal plots than non-IPM plots. Further the author mentioned that the farmers adopting IPM technology agreed that the sole pesticides control are costly and have health hazardous effect whereas IPM is convenient for handling and profitable. Mandal et al. (2008b) revealed that the IPM package with the practice of installation of pheromone trap, clipping of shoot, application of neem-based insecticides and removal of damaged fruits during harvesting performed well to reduce the problem of $L$. orbonalis in brinjal cultivation.

A study revealed that the Bio-intensive IPM with mechanical and chemical control of pest management performed well in controlling the $L$. orbonalis in brinjal cultivation (Adbhut Yadav et al., 2017). In addition Shanmugam et al., (2015) stated that the Bio-intensive pest management module was superior over Bio-rational and Farmer pest management modules with least shoot and fruit damages and high benefit cost ratio in brinjal cultivation. NSKE 5\% was effective in reducing the shoot and fruit infestation thus it was suggested to incorporation of NSKE 5\% in IPM modules (Chakraborty, 2001; Naitam and Mali, 2001; Rath and Maity, 2005; Yadav and Sharma., 2005). Besides, Hanumanthe Gowda et al., (2017) recorded that Biointensive management of L. orbonalis was a cheapest method to farmers with minimum yield loss in brinjal.

\section{Conclusion}

Bio-intensive IPM (BIPM) was found to be superior to farmer's practice in the aspectsviz., reduction in shoot and fruit infestation and enhancing the activities of natural enemies in the brinjal field experiment. Benefit cost ratio (BCR) ranked in the order of superiority as 
BIPM module (1:5.75), which was greater than the farmer practice $(1: 4.96)$ on brinjal.

\section{References}

Adbhut Yadav, Sachan S. K. and Arvind Kumar. (2017). Evaluation of some integrated pest management modules against shoot and fruit borer (Leucinodes orbonalis Guenee) in brinjal (Solanum melongena L.) Plant Archives17 (1): 457462.

Chakraborti, S. (2001). A biorational approach for the management of brinjal fruit and shoot borer, Leucinodes orbonalis Guen. J. Entomol. Res., 25(1): 73-76.

Doijode, S. D. (2001). Seed storage of horticultural crops (157). Haworth Press: ISBN 1-56022-901-2.

Hanumanthe Gowda, B., Ramesh, P. R. and Prashanth J. M. (2017). Biointensivemanagement of brinjal shoot and fruit borer, Leucinodes orbonalis Guen.: Technology demonstration and impact. Pest Management in Horticultural Ecosystems. 23(1): 60-63.

Krishnakumar, N. K. and Krishnamoorthy, P. N. (2001). Integrated Pest Management of insects damaging solanaceous vegetables. In: Integrated Pest Management in Horticultural Ecosystems. Reddy, P., A. Verghese and N. K. Krishnakumar (Eds.). Capital publishing company. New Delhi. $35-45$.

Krishnakumar, N. K. and Krishnamoorthy, P. N. (1998). Annual Report of Indian Institute Research, Bangalore, 15.

Lalitha Kumari, V. L. and D. D. R. Reddy. (1992). Evaluation of pheromone trap designs for trapping Spodoptera litura and Helicoverpa armigera and their reproductive behavior. Indian Journal of Plant Protection. 20: 18-23.
Loganathan, M., Sasikumar, M. and Uthamaswamy, S. (1999). Assessment of duration of pheromone dispersion for monitoring Helicoverpa armigera $(\mathrm{H}$.$) on$ cotton. J. Ent. Res., 23(1): 61-64.

Mandal, D., Baral, K. and Talekar, N. S. (2008b).Integrated pest management of brinjal shoot and fruit borer, LeucinodesorbonalisGuenee. Journal of Applied Zoological Researches, 19 (1): 4245.

Mandal, D., Ghosh, D., Baral, K., Roy, B. C. and Talekar, N. S. (2008a). Impact of IPM Strategy for Control of Brinjal Fruit and Shoot Borer, Leucinodes orbonalis

(Guenee).Annals of Plant Protection Sciences, 16(2): 399- 403.

Naitam, N. R. and Mali, A. K. (2001). IPM of brinjal pests using insecticide mixtures and natural enemies.Pest Management in Horticultural Ecosystem, 7(2): 137-140.

Niranjana, R. F., Devi, M., Shanika, W. and Philip Sridhar, R. (2015). Potential Use of Egg Parasitoids, Trichogramma pretiosum Riley and Trichogramma chilonis Ishii against Brinjal Shoot and Fruit Borer, Leucinodes orbonalis Guenée. Tropical Agricultural Research, 27 (1): 88 $-94$.

Patil, B. V. and Mamadapur. B. B. (1996). Performance of some sex pheromone traps and lures of Helicoverpa armigera (H.). Indian Journal of Plant Protection. 24(1\&2): 128-129.

Rath, L. K. and Maity, B. K. (2005). Evaluation of a non-chemical IPM module for management of brinjal shoot and fruit borer. J. of Appl. Zool. Res., 16(1) : 3-4.

Shanmugam, P. S., Indhumathi, K., Vennila, M. A. and Tamilselvan, N. (2015). Evaluation of biointensive pest management modules against brinjal shoot and fruit borer, Leucinodes orbonalis 
Guenee (Lepidoptera: Crambidae) under precision farming system. Pest Management in Horticultural Ecosystems, 21(2): 154-158.

Sidhu, A. S. and Dhatt, A. S. (2007). Current status of Brinjal research in India. In: Proc. $1^{\text {st } I C}$ on Indig. Veg. and Legumes. (Eds.) M. L. Chadha et al. Acta Hort., 752.

Talekar, N. S. (2002). Controlling eggplant shoot and fruit borer: A simple, safe and economical approach. International Cooperators' Guide, Publication No. 02534, Shanhua, Taiwan: Asian Vegetable Research and Development, Center.
Tsao, and Lo. (2006). In "Vegetables: Types and Biology". Handbook of Food Science, Technology, and Engineering by Yiu H. Hui.CRC Press. ISBN 1-57444551- 0. Zoological Researches, 19 (1): 4245.

Yadav, D. S. and Sharma, M. M. (2005). Comparative efficacy of bio-agents, neemproducts and malathion against brinjal shoot and fruit borer, Leucinodesorbonalis Guenee. Pest. Res. J., 17(2): 46-48. 